\title{
NOTAS PARA UMA APROXIMAÇÃO ENTRE A NOÇÃO NIETZSCHIANA DA 'MORTE DE DEUS' E O EXISTENCIALISMO DE SARTRE
}

\author{
[NOTES FOA AN APPROACH BETWEEN THE NIETZSCHIAN NOTION OF THE 'DEATH OF GOD' AND \\ THE EXISTENCIALISM OF SARTRE]
}

George Souza de Melo * Universidade Federal de Pernambuco, Brasil

\begin{abstract}
Resumo: Este artigo apresenta, basicamente, a noção nietzschiana da "morte de Deus", o existencialismo desenvolvido pelo filósofo francês Jean-Paul Sartre, e quais são as suas possíveis relações. Está dividido em três partes e utiliza-se, fundamentalmente, da análise de obras importantes dos filósofos, assim como também de seus importantes comentadores. Apesar de se fazer uma reflexão crítica acerca dos temas trabalhados, a análise deste artigo tem, majoritariamente, um caráter históricobibliográfico acerca das obras filosóficas dos autores.
\end{abstract}

Palavras-chave: morte de deus; liberdade; existencialismo; ateísmo
ABSTRACT: This article presents, basically, the Nietzsche's notion of the "death of God", the existentialism eveloped by Jean-Paul Sartre, and are their possible relations. It's divided into three parts and is used, fundamentally, of the analysis of important works of the philosophers, as well as of its important commentators. Although a critical reflection is made on the themes studied, the analysis of this article has, mainly, a historical-bibliographic character about the philosophical works of the authors.

KEYWORDS: death of god; freedom; existentialism; atheism

\section{INTRODUÇÃO}

Ste artigo examina a possibilidade de estabelecermos uma aproximação das
perspectivas filosóficas de Nietzsche e de Sartre - respectivamente a noção da "morte de Deus" e o existencialismo - a partir do ônus da ausência de "Deus" nas considerações específicas de cada um. Sobre tal relação, entendo que ambas as perspectivas parecem transitar pelo que posso chamar de território filosófico do nãoDeus, que seria basicamente a elaboração de um pensamento que desconsidere a ideia de "Deus", tal como forjada na cultura ocidental de acentuada influência greco-cristã. O não-Deus acaba sendo, pelo dois filósofos, algo do necessário, seja pela constatação histórico-filosófica do declínio dessa ideia como paradigma, seja pela necessidade de pressupô-lo como condição para o desenvolvimento de uma filosofia que trate da existência humana sem determinação a priori. No entanto, para que esse trabalho de aproximação entre ambos seja feito, apresentarei primeiramente de forma mais específica as perspectivas particulares dos filósofos para que a relação em seguida possa

* Mestre pelo Programa de Pós-Graduação em Educação (PPGE) da Universidade Federal de Pernambuco (UFPE); Bacharel e licenciado em Filosofia pela Universidade Católica de Pernambuco (UNICAP); Doutorando em Educação pela UFPE. E-mail: georgedemelosdb@gmail.com 
ser forjada.

Divido este texto, então, em três partes: nas duas primeiras partes, serão apresentadas algumas ideias relacionadas à moral ocidental e a noção da "morte de Deus", de Nietzsche, e ao existencialismo desenvolvido por Sartre; esta apresentação prévia dos conceitos serve de fundamentação para a parte conclusiva, na qual será, de fato, estabelecida a relação entre os filósofos em questão.

$\mathrm{Na}$ primeira parte, o desenvolvimento do trabalho tenta esclarecer o que significa a noção da "morte de Deus" na filosofia de Nietzsche. Para isso, tendo em vista a mirada nietzschiana em direção aos valores da cultura, é esboçada primeiramente uma apresentação acerca da moral ocidental para que, depois, se trate do conceito do filósofo. Percebe-se que é sob um prisma histórico que Nietzsche encontra a confirmação de sua ideia de que os valores são produtos culturais, desenvolvidos na esfera humana e mutáveis (o que era praticamente impensável na cultura de valores ideais, eternos e imutáveis).

A partir disso, fica mais claro o motivo pelo qual a noção da "morte de Deus" representa uma ruptura tão radical no solo da civilização ocidental, capaz de gerar o que o filósofo chama de niilismo. A consideração inevitável de que "Deus está morto" se apresenta justamente como o colapso dos valores morais na civilização ocidental. E mais ainda, como o colapso da própria civilização ocidental. A sua acentuada influência nos parece ser tão evidente nos nossos dias, que se torna possível o estabelecimento de uma relação com outros pensadores posteriores ao filósofo alemão. E por isso, a proposta deste trabalho é fazer isso em relação a Sartre.

A segunda parte, elucida o existencialismo sartriano, propriamente dito, com foco específico no conceito de liberdade trabalhado nesta perspectiva filosófica. $O$ homem livre, repleto de possibilidades, é o objeto central dos pensamentos do filósofo. E esta reflexão sobre liberdade só pode ser desenvolvida, segundo o próprio Sartre, sob a pena da ausência de "Deus". Livre para determinar sua existência, segundo o filósofo, o homem só pode se reconhecer, enquanto tal, se colocado fora de qualquer consideração que o determine a priori de seu surgimento existencial.

Apesar de ser aparentemente desoladora essa consideração, tenta-se, neste trabalho, esboçar de que forma o filósofo consegue convencer que sua filosofia é muito mais positiva do que essa aparência possa evidenciar. E, além disso, como tal perspectiva filosófica se apresenta enquanto encorajadora para o homem diante de suas responsabilidades.

No terceiro tópico, é promovida a possível forja e análise daquilo que estou chamando de território filosófico do não-Deus no que toca as possíveis relações entre as perspectivas filosóficas apresentadas anteriormente. Ouso afirmar que essa talvez seja a parte mais significativa do trabalho, tendo em vista todas as dificuldades em se aproximar teorias filosóficas distintas e relevantes como as que estão em questão. No entanto, o que apresento é, na verdade, um esboço de relação que seja capaz de instigar a crítica e a produção filosófica acerca das teorias que certamente não são impassíveis de relação.

Desde já, esclareço que este trabalho, de forma alguma, pretende provar que Sartre necessariamente tenha utilizado das ideias nietzschianas para o desenvolvimento de sua filosofia, apesar de sabermos que o filósofo foi leitor de Nietzsche ${ }^{1}$, ao ponto de citá-lo em sua obra $O$ ser e o nada ${ }^{2}$. O que, de fato, tento com este trabalho é mostrar de que forma as reflexões de Nietzsche acerca do anúncio da "morte de Deus" podem ecoar de modo significativo na filosofia posterior, principalmente, no que se refere ao existencialismo desenvolvido pelo filósofo francês.

Ao mesmo tempo, percebo que tal empreendimento parece ter sido pouco 
explorado por outros estudiosos, principalmente, pelo fato de encontrarmos aproximações entre as ideias de Sartre e de Nietzsche a partir do âmbito da literatura ${ }^{3}$ e em relação à questão da autenticidade ${ }^{4}$, mas, não em referência à questão da "morte de Deus" e a liberdade.

Desenvolvida a partir de pesquisa bibliográfica, a construção do texto foi auxiliada pela leitura de obras fundamentais dos filósofos em questão, tais como: $A$ gaia ciência, Assim falou Zaratustra, $O$ existencialismo é um humanismo e $O$ ser e o nada. Bem como pela leitura de outras obras de comentadores brasileiros e estrangeiros dos filósofos, entre eles, Scarlett Marton, Didier Franck, Roberto Machado, Paulo Perdigão, Gary Cox e outros.

\section{A MORAl ocidental, Nietzsche E a "MORTE de Deus"}

É com base em pressupostos históricos básicos constituintes da civilização ocidental que Nietzsche desenvolve a sua crítica à moral, particularmente, aos valores morais. A mudança de paradigma no Ocidente com o desenvolvimento da razão esclarecida representa muito mais do que uma simples transição. É promovida uma ruptura radical e uma transformação de pensamento, principalmente nos âmbitos do conhecimento, da religião e da moral, identificada pelo filósofo alemão como a catástrofe ocidental ${ }^{5}$. Isto significa que todo o edifício conceitual, moral e religioso, que determinava a cultura ocidental desde antiguidade, entra em colapso com as "luzes" trazidas pela razão. Com isso, segundo o filósofo, os elementos fundantes da civilização ocidental (um cristianismo socrático-platônico e a razão esclarecida) entraram em choque, gerando a necessidade de uma ressignificação de tudo que até então se tinha como verdades indubitáveis e determinantes, e que se dirigisse à noção paradigmática fundamental e determinante de todo um sistema cultural: Deus.

O mundo ocidental teve bem definido, em grande parte da história, Deus (dos cristãos) como o referencial sob o qual se delineava toda a moral. Uma moral focada em valores como, por exemplo, a "caridade", a "harmonia", a "ascese", na qual, "Deus" é tido como o bem supremo, eterno e imutável, considerado aquele que perdoa os que fraquejam na busca das virtudes verdadeiras. O cristianismo, continuando a consolidação monoteísta de raiz judaica, com o seu deus único e todo-poderoso, se torna após o Edito de Teodósio (380 d.C.), a cultura referencial para a civilização ocidental. O modo de se relacionar dos homens entre si e com o mundo se transforma, então, a partir da consolidação desta religião. $\mathrm{O}$ referencial teísta tomou o lugar absoluto de determinação da moral social e inaugurou, no Ocidente, uma cultura de valores e condutas específicos que se manteria quase que inabalavelmente dominante até a idade das luzes.

No entanto, a ocidentalidade não produz sua moral somente sob a influência de uma religião, como se esta representasse um grupo específico que não sofreu a influência de outros povos, como os gregos, por exemplo. Antes mesmo do cristianismo nascer e tomar força, encontramos nos gregos algumas contribuições para a moral ocidental que são de grande importância.

Platão, por exemplo, influenciado pelo orfismo, na constituição do que entendemos como significação moral para a vida terrena, insere diretamente o seu ensinamento sobre a imortalidade da alma e recompensas no além. Essas noções já podem ser observadas, por exemplo, na Apologia de Sócrates ${ }^{6}$, quando Sócrates sugere que ao chegar ao Hades, vamos encontrar os verdadeiros juízes que, segundo consta, lá distribuem justiça (PLATÃO, 1997). Dessa forma, o filósofo grego já coloca a 
consideração do além-vida como uma referência moral. Ou seja, a possibilidade da felicidade se encontrará no que está fora da vida terrena, fundamentando e dando sentido moral. E é no que está fora do plano terreno que também se encontra a justiça, o julgamento pós-morte. Podemos encontrar outros diálogos platônicos que tratam da mesma questão, mas, é no Fédon que o filósofo desenvolve claramente a sua defesa em relação ao julgamento da alma, no pós-morte, com o "mito do destino das almas" (PLATÃO, [198-?]). O que corrobora, então, que já no grego, o significado da vida terrena é dado pelo além.

Torna-se o papel do cristianismo nascente, assim, estabelecer a convergência das duas evidentes perspectivas morais no ocidente: a grega e a judaica. E o faz, portanto, vinculando a moralidade a um ideal de pessoa humana virtuosa. Sempre expurgando as influências naturalistas dos gregos, faz com que a moralidade seja entendida somente a partir de preceitos religiosos. Ou seja, o homem é virtuoso na medida em que busca viver segundo regras que o ajudam a alcançar a "paz infinita e a vida eterna". Regras dadas pelo Deus, primeiramente, no Sinai a Moisés, e depois a partir da pregação de Jesus Cristo.

É caminhando com os olhos no horizonte infinito do além-terra que o homem ocidental deve, sob a perspectiva cristã, fazer suas escolhas, buscar a felicidade, fugir das paixões e servir a Deus. Com a escolha desta moral, ele afirmava categoricamente a sua crença numa dualidade de mundos, e fixava todo o sentido de sua existência num plano que estava fora de seu alcance, num mundo ideal. Sempre foi na "casa de Deus" que este homem da moral cristã buscou sua habitação, em detrimento da sua verdadeira realidade latente. Foi a este projeto que ele entregou sua "liberdade" e construiu suas relações com os outros. Era a partir desta moral religiosa, centrada em Deus e na transcendência, que ele esperava obter sua realização plena, denominada "salvação". E tudo praticamente se resolvia dentro das paredes de uma religião.

Entretanto, com o desenrolar da história, percebemos que tais ideias não permaneceram intactas. Acontecimentos como a Reforma Protestante, por exemplo, começaram a forçar os limites dessa hegemonia católica e a abrir caminhos para novas constituições sociais não mais baseadas unicamente naquela cristandade.

A indiferença em relação à necessidade de uma religião que fundamente ou pelo menos ande de mãos dadas com a moral fez com que a discussão sobre a moral social se estabelecesse. Tudo caminhava, então, para o estabelecimento de que a moral seja essencialmente social e não religiosa, como se pensava. E foi o que aconteceu a partir dos séculos XVII e XVIII com o Iluminismo, marcando acentuadamente a cisão radical entre Igreja e Estado, e desestabilizando todo um edifício social construído sobre bases teológicas, dando início a um novo projeto para o Ocidente, o projeto da razão esclarecida.

Ao desenvolver sua ideia do colapso no Ocidente, Nietzsche, então, vai buscar na antiguidade grega e no desenvolvimento do cristianismo, os fundamentos que sustentam a sua defesa de que a mudança de um paradigma teológico para o desenvolvimento da razão no Ocidente deve ser verdadeiramente entendida como a "morte de Deus" ". Ao trabalhar essa noção, o filósofo identifica a mudança como a queda do valor maior (Deus) que determinava os valores morais no Ocidente, e isso faz com que, fundamentalmente, sua investigação se torne uma análise acerca dos valores morais.

O exame dos valores, de acordo com Nietzsche, deve partir da consideração de que eles são produtos de um processo histórico do desenvolvimento civilizatório e, por causa disso, são passíveis de mudança. Este tipo de consideração já é, de per si, radical demais dentro do contexto ocidental que, graças a uma herança dualista platônica, 
praticamente sempre teve os valores como propriedades de um mundo suprassensível perfeito e imutável ${ }^{8}$, em relação ao qual qualquer crítica resultaria insuficiente ${ }^{9}$. Além do que, como vimos sobre cristianismo, a ocidentalidade passou a se referir ao mundo das ideias perfeitas como divino, colocando "Deus" como o paradigma maior, a partir do qual todos os valores deveriam ser considerados. Desse modo, fica evidente que, para uma crítica mais profunda dos valores torna-se necessário, primeiramente, pôr em questão o referencial maior destes valores: Deus. E Nietzsche fez isso ao desestabilizar o paradigma maior, considerando-o como fruto de um processo histórico que já demonstrava sua ineficiência ${ }^{10}$.

O filósofo alemão, com isso, acena para o grande problema já instaurado no mundo ocidental e que ainda não havia sido de todo compreendido: a falta de "lugar" para Deus, proporcionada pelo avanço da ciência e a virada antropocêntrica. Com o Iluminismo, no século XVIII, todo o pretenso mundo teologicamente ordenado se desestabiliza já que passa-se a ser questionada, com a razão, a noção de "Deus" como sendo a única fonte de ordenação das coisas. A ideia do Universo, estruturado através da hierarquia cósmica dos graus de perfeição norteados pelo divino, já não se sustentaria com o avanço das ciências que se apoderam dos fenômenos naturais, no anseio de ter-lhes o controle. E isso significa, a seu ver, uma desconstrução paradigmática radical no seio da civilização ocidental, que pode ter seus efeitos prolongados por muito tempo ${ }^{11}$.

A consideração da "morte de Deus", segundo o filósofo, direciona a cultura para o niilismo que, como sentimento de vazio, de falta de algo que sirva como uma bússola para existência, pode causar desamparo. O niilismo é a sensação própria dos órfãos do antigo paradigma. E todos os que vierem após a constatação da queda dele estão condenados a esse sentimento. Condenados ao vazio, à sensação de desnorteados, conforme as interrogações que são apresentadas na seção 125 de $A$ Gaia Ciência:

Que fizemos nós, ao desatar a terra do seu sol? Para onde se move ela agora? Para onde nos movemos nós? Para longe de todos os sóis? Não caímos continuamente? Para trás, para os lados, para frente, em todas as direções? Existem ainda 'em cima' e 'embaixo'? Não vagamos como que através de um nada infinito? Não sentimos na pele o sopro do vácuo? [...] Deus está morto! Deus continua morto! E nós o matamos! Como nos consolar, a nós, os assassinos entre os assassinos? (NIETZSCHE, 2012. p. 137-138).

A partir disso, é preciso, portanto, encontrar um novo caminho, eleger ou descobrir uma nova guia para sua existência. Porém, no vazio o homem só encontra a si, e desta forma, percebe-se como detentor do seu caminho "existencial", criador dos valores que significam o seu existir, inclusive, criador dos seus deuses. Sabedor de sua capacidade criadora, o homem pode de forma mais evidente entender a "morte de Deus". E entender-se totalmente responsável por ela, como também igualmente responsável por uma nova perspectiva que preencha o espaço vago deixado pela sua adesão.

Esta concepção do homem que se autoconhece e que se inquieta em relação ao que fazer após o "assassinato" de Deus é ilustrada por Nietzsche, na seção 153 (Homo poeta) de A Gaia Ciência. Nela, o filósofo apresenta justamente o homem tomado como consciente do deicídio provocado por ele mesmo - "eu próprio matei agora todos os deuses" (Nietzsche, 2012, p. 149), e incumbido de dar uma resposta satisfatória em relação ao sentimento de "vazio existencial". Assim sendo, parece claro que o niilismo não somente deve ser entendido como um sentimento de ausência (do nada), mas, também como um propulsor de responsabilidades para o homem. Responsabilidades 
que agora se colocam diante da necessidade de repensar os valores morais sem a instância divina que os tutelavam. E, para essa complexa tarefa, aquele "homem dualista" já não é suficiente. O que surge como projeto necessário agora é o superhomem [além-do-homem], trazido pelo filósofo em Assim falava Zaratustra (2011), mas que não será necessariamente objeto central desta nossa investigação.

Por último, vale salientar que na seção 343 de A Gaia Ciência, Nietzsche talvez nos presenta o que seja a sua maior expectativa ao trabalhar a noção da "morte de Deus": a esperança de novos tempos, de novas possibilidades de reflexão sem as amarras impostas pelo velho paradigma teísta; o vislumbrar de "uma nova aurora", como o próprio filósofo diz.

$\mathrm{Na}$ sombra do apagar "Deus", novas luzes se acendem para os filósofos. É possível, portanto, repensar tantas coisas que até então eram relegadas somente à autoridade divina, inclusive, os valores. Eles deverão ser criticados e repensados agora sob outro critério. Por essa seção, pode-se levar em consideração a relevância que o filósofo dá na sua constatação histórica ao evento iluminista da razão emancipada. Mesmo não sendo um defensor da predominância deste tipo de concepção da razão, pois defende a importância da consideração de todos os impulsos vitais no homem, Nietzsche não deixa de reconhecer o quão benéfica representa a efetivação do Iluminismo no Ocidente. Segundo ele, é, de fato, uma felicidade para o desenvolvimento ocidental a emancipação da razão crítica. Com ela, os filósofos anseiam fortemente o desbravamento de um horizonte epistemológico que até então parecia inacessível, e que agora se mostra com ares de liberdade. A partir desta nova conjuntura de possibilidades, os valores morais (desprovidos da instância divina que os tutelavam) deverão ser repensados.

Como não é do intuito deste trabalho tratar de como o filósofo propõe essa transvaloração da moral, partimos, então, a analisar a utilização da noção da "morte de Deus" em Assim falava Zaratustra (2011). Nessa obra, o nosso filósofo coloca para o personagem principal a missão de anunciar a "morte de Deus" aos homens que ainda a desconhecem.

Desde o prólogo, numa evidente analogia à tradição grega (Platão) e a Cristo, Nietzsche começa a desenvolver a história de Zaratustra, personagem principal de sua trama. Este artifício de elaboração textual não foi escolhido por acidente, mas justamente como uma tentativa de mirada crítica em direção a toda a tradição ocidental, principalmente no âmbito moral já esboçado neste trabalho. Certamente, no Zaratustra, o próprio Nietsche se coloca. E a partir dessa personagem ele tenta afirmar-se como aquele que irá inaugurar uma nova perspectiva paradigmática no ocidente.

Zaratustra, ao descer da montanha, após ficar dez anos por lá em contemplação, sai pelos vilarejos a espalhar o seu projeto de anunciar o além-do-homem, só efetivamente encontrado num contexto posterior à "morte de Deus" (MACHADO, 1997). Logo com o primeiro que encontra em seu caminho, um velho eremita, o santo já identifica que a ideia de que Deus morreu ainda não está muito disseminada pelo mundo, e continua seu caminho. Aos próximos que encontra, anuncia de fato o alémdo-homem: o homem esclarecido a tal ponto que já não aceita determinantes supraterrenos, mas, que permanece fiel à sua condição terrena. Aqui, já nesta cena do Zaratustra, percebemos ilustrada a catástrofe ocidental.

O além-do-homem renega a dualidade (terreno e supraterreno) estabelecida pela tradição ocidental que, no entender do Nietzsche, representa um veneno à vida. Com essa negação do supraterreno, do divino, já não há mais ofensa como antes era entendida. Na verdade, o quadro se inverte a partir do choque de paradigmas e o critério que deve ser levado em consideração é o critério da vida. De modo que, também, as 
ofensas que podem ser cometidas a partir de então serão ofensas à vida.

Dessa forma, a virada de consideração a partir da catástrofe no Ocidente é o que identifica justamente a passagem do homem ao além-do-homem: a passagem para o estágio mais elevado a que o homem pode chegar. $\mathrm{O}$ projeto de humanidade que não busca mais primeiramente atrás das estrelas uma razão para declinar e ser sacrificado, mas que se sacrifica à terra (NIETZSCHE, 2011), é justamente o homem que está nesta passagem ${ }^{12}$, em busca do seu declínio. É estabelecendo, pois, a passagem ao além-dohomem, fundamentalmente marcada pela desconsideração de Deus, que Nietzsche, nessa obra, desenvolve de certa forma o evento da catástrofe ocidental.

Essas considerações nos levam a entender, a grosso modo, o que significa e quais são as consequências, então, de uma constatação de não-Deus para a cultura e humanidade a partir da perspectiva filosófica do pensador alemão. Agora, na seção seguinte deste trabalho, partiremos para um esboço de como uma consideração de nãoDeus pode ser encontrada na filosofia existencialista de Jean-Paul Sartre, de modo que satisfaça uma possível aproximação dos filósofos em questão na parte conclusiva do trabalho.

\section{O EXISTENCIALismo EM SARTRE}

É a partir do conceito de liberdade e permanentemente centrado nele que o existencialismo sartriano se desenvolve. E devo dizer desde agora que essa amálgama existência-liberdade é também fundamental para o que entenderemos como o não-Deus na filosofia dele.

Despida de qualquer substância essencial ${ }^{13}$, a existência para Sartre é, com o seu despontar, unicamente liberdade. Em $O$ existencialismo é um humanismo (2012), o filósofo diz claramente que o "homem é liberdade". Localizado particularmente no universo do humano, o pensamento deste filósofo sobre liberdade está intrinsicamente ligado à ideia de ação:

Agir é modificar a figura do mundo, é dispor dos meios com vistas a um fim, é produzir um complexo instrumental e organizado de tal ordem que, por uma série de encadeamentos e conexões, a modificação efetuada em um dos elos acarrete modificações em toda a série e, para finalizar, produza um resultado previsto. Mas ainda não é isso que nos importa. Com efeito, convém observar, antes de tudo, que uma ação é por princípio intencional. (SARTRE, 2014, p. 536).

Percebe-se a partir disto que o agir para Sartre pressupõe uma consciência intencional em relação ao projeto que se pretende, mesmo que não se possa prever as consequências do ato. Ou seja, para que toda ação se efetive, é preciso tender-se a algo, mesmo sem saber exatamente o que se sofrerá com tal ação. ${ }^{14}$ No entanto, vale ressaltar que para que o ato se complete, de fato, é preciso a adequação do resultado à intenção inicial. Dessa forma, entende-se que devido à falta de domínio prévio dos resultados de um ato, toda ação implica necessariamente uma negatividade que o filósofo chama de "falta objetiva". E isso significa dizer que, "desde a concepção do ato, a consciência pode se retirar do mundo pleno do qual é consciência e abandonar o terreno do ser para abordar francamente o do não ser" (SARTRE, 2014, p. 537). Sendo neste movimento da consciência que se lança no possivel a partir da inversão do que está dado onde efetivamente a liberdade se desenvolve.

É a partir desse sentido de condição para toda ação que Sartre começa a entender a liberdade. Porém, mesmo com isso, algumas questões ainda nos surgem, como do tipo: que tal liberdade será essa? E, será que é possível descrevê-la levando em 
consideração a sua falta de essência, já que é localizada na "falta objetiva" que impulsiona as ações? O próprio filósofo se depara com este problema em sua obra $O$ ser e o nada e tenta resolvê-lo tomando a "liberdade" a partir de uma consideração análoga ao que ele entende como o dizer de Heidegger sobre o Dasein, no qual a existência precede e comanda a essência.

Sartre enfatiza o caráter individual da liberdade, enquanto minha liberdade, para banir a possibilidade de consideração de uma essência da liberdade. Ou seja, uma liberdade comum ao eu e ao outro. Para o filósofo francês, "ao contrário, a liberdade é fundamento de todas as essências, posto que o homem desvela todas as essências intramundanas ao transcender o mundo rumo às suas possibilidades próprias" (SARTRE, 2014, p. 542). Assim, o homem é um existente que aprende sua liberdade através de seus atos, tornando-se, dessa forma, consciência de liberdade.

A ação do homem é fundamental para entendermos a liberdade. Como o filósofo aponta, na ação, fundamentalmente condicionada à liberdade, a nadificação do Em-si se efetiva $^{15}$. Só se age intencionalmente, ou seja, com vista num fim, criando-se o motivo da ação que desde sempre está fora daquilo que é. Em termos satrianos, um ato é a projeção do Para-si rumo a algo que não é ${ }^{16}$. É isso que move toda ação e, portanto, a liberdade não é outra coisa senão essa potência de nadificação do Em-si. Assim, para o Para-si, o ser é sempre possibilidade, é sempre essa ruptura com o que é (essência), sendo sempre esta nadificação. Por isso que, sempre propenso à nadificação de tudo, o homem é condenado a ser livre.

No entanto, para uma melhor compreensão dessa liberdade como nadificação do que é (Em-si) - da realidade humana como capaz de realizar esta ruptura nadificadora com o mundo e consigo mesma (BORNHEIM, 1984) - é necessário compreendermos o seu modo particular de existência. Modo este que, como já dissemos, não é precedido de uma essência e que fundamenta a máxima central do existencialismo de Sartre: a existência precede a essência.

O existencialismo desenvolvido por Sartre tem como afirmação principal a de que a existência fundamentada no princípio da liberdade precede a essência. $\mathrm{Na}$ esteira do que já vínhamos tratando, tal afirmação atesta claramente que, a partir da liberdade, o Para-si (homem) escapa à sua essência. Ou seja, dele não se pode dizer nada a priori. O Para-si está para além do que se pode dizer dele ou da propriedade que se queira atribuir a ele. Não se pode, portanto, identificar-lhe por uma determinação essencial. Ele em seu desenvolver-se transita pelos caminhos do possível, do que está fora da estrutura essencial do ser-em-si (do que já é, de fato), impossibilitando qualquer consideração essencial acerca de si. ${ }^{17}$

Entretanto, deixando de lado um pouco o arcabouço teórico mais filosófico do Ser e o Nada, tomemos a linha explicativa dada pelo próprio Sartre em $O$ Existencialismo é um Humanismo para entendermos de forma mais clara sua máxima existencial. Na conferência citada, ele explica sua teoria filosófica de maneira mais compreensível, tomando, por exemplo, o Ser-Para-si sempre como o homem. Pois bem, em oposição a toda uma tradição essencialista, o filósofo defende que não existe uma essência a priori que determine a existência do homem. O homem primeiro existe para depois definir o que irá ser. Como, então, entender que a existência precede a essência? Antes, partamos primeiramente do inverso (a essência precede a existência) para percebermos de que modo se encaixa a consideração central do filósofo.

À maneira sartriana de explicação, tomemos o exemplo da fabricação de um objeto comum para entendermos a questão. Quando um artífice pensa em fabricar algum determinado objeto, certamente, de início ele já tem noção de como ficará tal objeto e para que servirá. E se põe a fabricá-lo. De modo que, quando pronto, o objeto 
já terá definidas todas as suas características formais e finais. Estas características atribuídas aprioristicamente ao objeto é o que chamaríamos de "essência". Ou seja, aquilo que constitui o objeto, que o determina tal como ele é, e que o impossibilita ser de outra forma.

Podemos pensar de forma semelhante sobre o homem se o tomarmos por uma concepção essencialista. Se consideramos que há um artífice (Deus) que pensa o homem para poder fazê-lo, necessariamente estamos aceitando a atribuição de características prévias que dão condição ao que seria o "homem". Dessa forma, ratificamos a ideia de que há uma essência a priori no homem, e confirmamos a noção de que essa essência precede a existência dele. Destarte, foi sob essa consideração de criação divina, como vimos com Nietzsche, que toda uma cultura (ocidental) se desenvolveu por muito tempo, a partir da linha cristã de explicação do mundo e das origens do homem. No entanto, o que Sartre propõe é a inversão disso: a existência precede a essência. E essa inversão somente se justifica a partir da desconsideração daquele artífice (Deus), responsável pela criação do homem.

A noção de que não existe um Deus que cria o homem e que lhe atribui uma essência é fortemente propícia para o desenvolvimento da relação existência-liberdade fundamental no pensamento do filósofo. E é, nesse sentido, que encontramos a necessidade da desconsideração de Deus (não-Deus) para o desenvolvimento de sua filosofia existencialista.

Para Sartre, o homem primeiro surge no mundo para a partir disto definir o que será. Esta concepção solitária dá ao homem o caráter de posse de sua própria existência. Ele, dono de si, sem ter alguém que determine o seu destino, deve escolher como será o roteiro de sua existência e nada mais. Tendo de escolher sempre, o homem se percebe fundamentalmente "liberdade". E sendo assim, segundo o filósofo, a posição ateia do existencialismo é, então, a que mais consegue fundamentar tal possibilidade de relação existência-liberdade ${ }^{18}$ :

O existencialismo ateu, que eu represento é mais coerente. Ele declara que, se Deus não existe, há pelo menos um ser no qual a existência precede a essência, um ser que existe antes de poder ser definido por qualquer conceito: e que esse ser é o homem ou, como diz Heidegger, a realidade humana [...] Isso significa que o homem primeiro existe, se encontra, surge no mundo, e se define depois. [...] Assim, não há natureza humana, uma vez que não há um Deus para concebê-la. $\mathrm{O}$ homem apenas é, não apenas tal como ele se concebe, mas também como ele se quer; e como ele se concebe após a existência, como ele se quer após esse elã em direção à existência; o homem nada mais é do que aquilo que ele faz de si mesmo. Esse é o primeiro princípio do existencialismo. (SARTRE, 1970, p. 21-22, tradução nossa).

Para Sartre, é mais convincente sustentar a não precedência de uma essência (ser) a partir da desconsideração de um artífice (Deus) criador do homem. Principalmente porque o filósofo não aceita a concepção criacionista do ser a partir de Deus. Para ele, a doutrina que se refere ao deus que cria ex nihilo é insuficiente para sustentar a criação do ser, pois, este, tomado como produto de uma subjetividade divina, permaneceria no modo de ser intrassubjetivo, impossibilitado, portanto, de ser afetado pela vontade de criar o objetivo. De modo que, tal subjetividade não poderia ter a representação de uma objetividade - o que descartaria a possibilidade do ser pensado objetivamente.

A mesma insuficiência explicativa encontramos se imaginarmos o ser fora do âmbito da subjetividade divina, pois teríamos que tomá-lo como contra e para o seu criador. Ou seja, o ser frente a Deus. Já que, se assim não fosse, o ser teria que 
necessariamente estar unido a Deus, sendo uma só e mesma coisa. E isso poderia se dar num retorno ao seu criador, logo após a criação. Das duas vias, percebemos que esta concepção do ser fora da subjetividade divina é a que mais dificulta a possibilidade de se tirar do ser a sua autossuficiência. Pois, sendo o ser si mesmo, ele é a sua própria sustentação. E isso expurga qualquer vestígio de criação divina, revelando-o como incriado (SARTRE, 2014).

Concluímos, portanto, que para Sartre, a melhor compreensão da realidade humana se dá pela consideração ateia da existência como precedente de uma essência. Ou seja, para entendermos mais coerentemente a máxima de que a existência precede a essência no homem, necessariamente devemos descartar, a priori, a possibilidade da criação deste por um deus. Assim, tudo o que se poderá delinear sobre o que caracteriza a existência do homem, e também tudo o que o homem poderá definir como sua essência, fundamentalmente não levará em conta as possíveis intervenções ou influências de uma ideia divina. Nesse sentido, o homem é, então, para Sartre, um existente que não está sob a guarida de um deus. Ele é o que o próprio filósofo chama de "um desamparado" (SARTRE, 2012, p. 34). E o desamparo (délaissement) é, pois, algo que caracteriza fortemente a existência do homem para o existencialismo sartriano.

Quando se fala em "desamparo" para o existencialismo sartriano, se refere justamente à desconsideração da existência de Deus levada ao preço de todas as suas consequências. E isso incomoda o existencialista. Porque não se trata de eliminar Deus apenas dogmaticamente e ainda considerar certos determinantes ou valores a priori na existência. Se trata de desconstruir mesmo qualquer terreno ontológico apriorístico sobre o qual se poderia erguer o edifício da existência humana.

É o mesmo que dizer que não tendo Deus, então não temos nenhum paradigma externo que sirva de referencial para o estabelecimento de determinadores fundamentais da estrutura de nossa existência. Estamos, de fato, sós. Isso nos faz questionar sobre de onde virão esses referenciais e quem estabelecerá os valores. E a resposta é fácil e clara: do próprio homem. Ele é que definirá o seu estar no mundo e quais serão os valores válidos.

É, portanto, desamparado que o homem se percebe como o único responsável pela sua existência. Se ele escolhe algo, não o faz, então, porque um deus ou algo semelhante the disse que era para fazê-lo. Mas, simplesmente, porque necessariamente sua existência é feita unicamente de escolhas, e disso ele não pode escapar. O próprio desejo de querer fugir da escolha já é, antes de mais nada, uma escolha feita. Portanto, o homem consciente de sua condição existencial sabe que é responsável pelas consequências advindas de suas escolhas. E a função principal do pensamento existencialista é fazer repousar no homem essa consciência de responsabilidade por si.

Não há espaço, então, para se colocar um "céu" no qual estarão as recompensas de seus atos, nem um juízo final em que serão pesadas todas as suas escolhas. Não há possibilidade para a aproximação entre a concepção existencialista e a escatologia cristã, tão influente no desenvolver da cultura ocidental. O universo humano, unicamente tomado dentro de seus limites, é posto como referencial central que deve ser levado em consideração.

Percebemos com isso, uma espécie de "virada paradigmática" que se desenvolve a partir de um movimento em que se coloca o homem no "trono" que sempre foi utilizado por "Deus". Sentado nele, o homem pode, portanto, instituir ou determinar tudo o que poderá constituir a existência humana, algo que culturalmente até então só se efetivava a partir dos comandos do divino. E é assim, então, que o existencialismo se coloca como uma doutrina fortemente otimista em relação ao homem diante de sua existência. 
O homem é, na concepção existencialista, o senhor de sua vida. Desta forma, é preciso sempre se inventar o homem a cada instante. O homem existencialista, desamparado, é precisamente assim, indefinível, pois se constitui como uma constante construção. Por isso, a definição mais plausível acerca dele, de acordo com estes preceitos, é a de que é liberdade. Para o homem desamparado, não há sentido em escolher acerca de algo que esteja fora do universo humano como, por exemplo, num âmbito divino. Assim como, também, dada a impossibilidade de se transpor à subjetividade para se ter acesso às subjetividades alheias, a escolha do existencialista sempre irá se referir ao homem em geral, ou seja, a todos os homens. Pois, ao escolher algo para si, ele atesta que este algo é o melhor para todos os homens. O desamparo, nesse sentido, coloca para o humano as responsabilidades por suas escolhas e passa a determinar radicalmente a constituição ética da vida.

Compreendidos esses elementos conceituais básicos da liberdade no existencialismo de Sartre, podemos concluir que nesta corrente filosófica não há relação mais equivalente do que a que se estabelece entre o humano e a liberdade, e que esta relação só é possível sob a pressuposição do não-Deus. São concepções que praticamente se fundem e não permitem a possibilidade de pensá-las separadamente, de forma que uma não necessite da outra e vice-versa. A compreensão de ambas as concepções se dá necessariamente pela pressuposição de uma sob a outra, devido, principalmente, ao entrelaçamento filosófico tecido pelo filósofo francês que consolida o peso dessa relação fundamental. A liberdade enquanto o nada sendo no âmago do homem desamparado se assemelha totalmente com o Para-si (homem) propulsor da nadificação, unicamente existente devido à própria capacidade de nadificar. Assim, aquela condena este a si. De modo que, não há melhor definição de liberdade na filosofia de Sartre que a afirmação de que a "liberdade não é um ser: é o ser do homem, ou seja, o seu nada de ser" (SARTRE, 2014, p. 545).

\section{NiETZSChE E SARTRE NO TERRITóRIO FILOSÓFICO do NÃo-DEUS}

De acordo com o desenvolvimento das seções anteriores, percebemos que os dois filósofos, compartilham, cada um ao seu modo, de um espécie de negativa de "Deus" enquanto um princípio ou ideia reguladora (o que estou chamando de nãoDeus), e que isso se apresenta como elemento importante para suas ideias. É a partir disso, então, que podemos postular que ambas as perspectivas filosóficas, apesar de muito específicas e diferentes, parecem-nos transitar por um território filosófico comum cuja tônica principal para a elaboração de pensamento seja a desconsideração radical dessa ideia de "Deus" juntamente com toda a carga histórica, filosófica e cultural que a constitui enquanto algo regulador e/ou princípio fundacional.

Nietzsche toma a descrença em Deus principalmente a partir de suas investigações acerca da história e do desenvolvimento da civilização ocidental. Assim, para ele, tal acontecimento juntamente com suas consequências evidentemente não podem ser negados. Destas consequências, percebemos a ênfase dada pelo filósofo à questão do niilismo, do vazio de valores essenciais para a conduta humana, e o quanto isso é importante para o desenvolvimento de sua filosofia do além-do-homem. Esta concepção nietzschiana é basicamente o que ele entende como o mais elevado grau de efetivação da potência de vida a que o homem pode chegar em sua existência, e como tal, deve ser insistentemente buscada pela cultura ocidental.

Sartre, por sua vez, se ocupa da desconsideração da existência de Deus como uma condição fundamental para a construção de sua filosofia existencialista. Todo o 
projeto filosófico pensado por ele para que a existência humana alcance a sua maior coerência e a sua maior liberdade de constituir-se, passa necessariamente por essa desconsideração. Ou seja, para o filósofo francês o que mais caracteriza a existência humana evidentemente como tal é a liberdade que só pode ser entendida de forma mais sensata e coerente se desconsiderar qualquer determinação a priori de si. E, nesse caso, não há lugar para "Deus".

Dessa forma, já podemos evidenciar que, ao analisar a noção nietzschiana da "morte de Deus" e o existencialismo desenvolvido por Sartre, é possível postular uma espécie de eco entre as perspectivas filosóficas, se não graças à proximidade histórica de ambos os filósofos (e não é nosso objetivo provar isso neste trabalho), mas, pelo menos, em termos de relação conceitual. Assim, nos parece evidente que o anúncio do filósofo alemão nos fins do século XIX nos soa como muito propício para a elaboração do pensamento sobre a existência que Sartre irá desenvolver, pelo menos, meio século depois. O ateísmo do filósofo francês parece-nos que se desenvolve de maneira semelhante, por exemplo, ao conteúdo dos brados incompreendidos expressados pelo "homem louco" em A Gaia Ciência, §125. Ao mesmo tempo que, nas entrelinhas das ideias nietzschianas parece-nos também que há espaço para se pensar como que um esboço do que seria desenvolvido em termos de liberdade no Existencialismo é um Humanismo, do filósofo francês.

Quando Sartre desenvolve sua ideia de liberdade, profundamente fundamentada pela desconsideração total de Deus como artífice do homem, ele nos deixa claro que no seu existencialismo é preciso levar essa consideração ateísta (do desamparo) até as últimas consequências. Ou seja, pagar todo o preço por tal posição, conforme atesta: "Quando falamos de desamparo [...] queremos dizer apenas que Deus não existe, e devemos assumir todas as consequências disso. O existencialista se opõe fortemente a um tipo de moral laica que pretende suprimir Deus pagando o menor preço possível" (SARTRE, 2012, p. 31).

Notamos com esse trecho que, para o filósofo, não adianta suprimir a ideia de Deus como inútil ou ultrapassada e mesmo assim adotar valores ou princípios de vida existentes anteriormente à existência humana. Segundo ele, os professores franceses fizeram isso ao esboçarem uma moral laica, e dessa posição discorda:

Em 1880, quando os professores franceses tentaram constituir uma moral laica, eles disseram mais ou menos o seguinte: Deus é uma hipótese inútil e custosa, vamos suprimi-la. Porém, para que exista uma moral, uma sociedade, um mundo que respeite as leis, será necessário que alguns valores sejam levados a sério e considerados como existentes a priori. (SARTRE, 2012, p. 31).

Sartre, assim, os reprova e considera-os como um tipo dos que não levam às últimas consequências a descrença em Deus.

Em relação a esse caso, encontramos outra sugestiva semelhança com Nietzsche, no trecho em que o "homem louco" de A Gaia Ciência, ao ir ao mercado anunciar a "morte de Deus", encontra os que já não criam em Deus que, não atentos ao que isso significa em termos de reconfiguração cultural, não conseguem compreender os brados do mensageiro: "E como lá se encontrassem muitos daqueles que não criam em Deus, ele despertou com isso uma grande gargalhada" (NIETZSCHE, 2012, p. 137). Esses descrentes indicados por Nietzsche são justamente aqueles que não levam às últimas consequências a sua descrença. Pois, a "morte de Deus" é de tal grandeza para o desenvolvimento da civilização ocidental que eles ainda não haviam compreendido a necessidade de sua radicalidade. Por essa razão, quase na conclusão da seção, o "homem louco" diz: 
Este acontecimento enorme está a caminho, ainda anda: não chegou aos ouvidos dos homens. O corisco e o trovão precisam de tempo, a luz das estrelas precisa de tempo, os atos, mesmo depois de feitos, precisam de tempo para serem vistos e ouvidos. Este ato ainda lhes é mais distante que a mais longínqua constelação $-e$ no entanto eles o cometeram! (NIETZSCHE, 2012, p. 138).

Percebemos, com isso, que os professores franceses citados por Sartre se aproximam muito "daqueles que não criam em Deus" (p.137), tratados por Nietzsche em A Gaia Ciência (2012). No entanto, resguardando as devidas diferenças de cada uma das perspectivas filosóficas, o que podemos produzir a partir dessa possível aproximação é que o evento anunciado por Nietzsche marca uma transição civilizacional de tal modo radical no que diz respeito à postulação e transvaloração dos valores que, mesmo meio século depois, uma filosofia da existência precisa ainda reafirmar e reforçar a evidente necessidade dessa consideração.

Dando seguimento à nossa análise, salientamos que o filósofo alemão também retoma às consequências da "morte de Deus" enfatizando que é necessário que o alémdo-homem as vença, como que extinguindo toda espécie de sombra de Deus que ainda insista em permanecer. Ele diz: "Deus está morto; mas, tal como são os homens, durante séculos ainda haverá cavernas em que sua sombra será mostrada. - Quanto a nós - nós teremos que vencer também a sua sombra" (NIETZSCHE, 2012, p. 126). O que nos mostra, ao retomar a perspectiva sartriana que, nesse sentido, segundo os filósofos, a consideração da "morte" e/ou "ausência" de Deus não representa algo simples de se assumir, mas justamente um grande problema.

Nietzsche entende essa dificuldade como relacionada ao perigo do niilismo - o sentimento da ausência dos valores que sempre guiaram as condutas do existir no mundo ocidental - deixando os homens que tem acesso a tal conhecimento num estado de desamparo, evocado claramente pelas palavras do "homem louco". E Sartre também confirma esta identificação do problema quando se refere ao vazio de valores a priori obtido pela desconsideração de Deus. A aproximação entre os filósofos em relação aos sentimentos da ausência de "Deus" pode ser identificada, por exemplo, com os trechos de Nietzsche que desenvolvem várias indagações a partir da consideração do declínio daquele paradigma:

Que fizemos nós, ao desatar a terra do seu sol? Para onde se move ela agora? Para onde nos movemos nós? Para longe de todos os sóis? Não caímos continuamente? Para trás, para os lados, para frente, em todas as direções? Existem ainda 'em cima' e 'embaixo'? Não vagamos como que através de um nada infinito? Não sentimos na pele o sopro do vácuo? [...] Deus está morto! Deus continua morto! E nós o matamos! Como nos consolar, a nós, os assassinos entre os assassinos? (GC, §125, 2012, p. 137-138).

E de Sartre (2012, p. 32):

O existencialista [...] vê como extremamente incômodo o fato de Deus não existir, pois com ele desaparece toda possibilidade de encontrar valores em um céu inteligível; não é mais possível existir um bem a priori, uma vez que não existe mais uma consciência infinita e perfeita para concebê-lo, não está escrito em lugar nenhum que o bem existe, que é preciso ser honesto, que não se deve mentir, pois estamos exatamente em um plano onde há somente homens.

O filósofo francês é bem enfático em relação ao problema de Deus não existir principalmente para se opor ao que ele tinha chamado de moral laica, aquela que havia sido proposta por professores franceses no século anterior e que suprimia a ideia de Deus, pois a consideravam uma hipótese inútil (como já tratamos). Só que, para a 
existência de uma sociedade, essa moral considerava ao mesmo tempo que seria necessária a existência de valores a priori, como, por exemplo: a honestidade, a autenticidade, o respeito à mulher. E o filósofo põe-se logo a desaprovar isso, colocando no humano, com todas consequências possíveis, a capacidade de determinar os valores.

Segundo seu existencialismo, somente o homem é capaz de dizer o que será na sua existência, mesmo levando em consideração as influências de toda a conjuntura social em que se está inserido desde o seu nascimento. O homem existencialista, portanto, não se "agarra" nas estrelas (num "céu inteligível", supracitado nas palavras de Sartre) para encontrar o que deve fazer de si nem o que deve escolher em relação à sua existência.

Para os filósofos, então, toda existência humana se dá unicamente no mundo terreno, neste aqui onde de fato ela se efetiva. Não há razão pela qual se deve esperar dos céus um significado para a existência. E isso, segundo eles, é o que há de mais importante. Pois, como que escapando do problema através da consciência de seu projeto, o "homem" encontra em ambas as concepções dos filósofos um impulso positivo em relação ao desenvolvimento de sua existência. Encontra-se - o humano nelas como uma abertura às possibilidades de ser (principalmente na filosofia de Sartre e também, por exemplo, na seção 374 de $A$ Gaia Ciência $^{19}$ ).

O ser "possibilidades", de acordo com o pensamento sartriano, é praticamente o que ele admite como sendo o que há de mais otimista no pensamento sobre o homem. A partir do seu engajamento, da sua ação, o homem então define-se e, ao mesmo tempo, se afirma como um constante indefinido a construir-se; uma pura possibilidade. Para o filósofo, essa é uma prova evidente de que o seu existencialismo não se esgota num ilusório caráter pessimista da "morte de Deus" com suas consequências indesejáveis, mas, ao contrário, vê na própria consideração ateia a grande chave que abre ao homem as possibilidades de ser o que realmente ele quer ser: "Vocês veem que ele não pode ser considerado [...] uma descrição pessimista do homem: não há doutrina mais otimista, pois ela coloca o destino do homem nele mesmo" (SARTRE, 2012, p. 45).

De forma semelhante, em Nietzsche, também encontramos mais do que um possível pessimismo gerado com a "morte de Deus". Na verdade, encontramos nisso a possibilidade de se superar o homem ocidental, tal como ele foi feito até agora: um dualista que espera do inteligível as justificativas para suas questões e valores. É com a desconsideração de Deus que o projeto nietzschiano do além-do-homem pode ser levado a cabo e, portanto, não há que se tomar tal consideração como negativa, mas simplesmente como evidente.

Desprezar a ideia deste grande referencial que sempre ditou as regras do jogo no Ocidente, por mais que os teístas contestem, é, segundo o filósofo, algo que historicamente pode ser notado e que, de certa forma, contribuiu em grande parte para o desenvolvimento de muitos âmbitos do conhecimento, especialmente, quando se trata do conhecimento científico.

$\mathrm{O}$ niilismo, mesmo que à primeira vista pareça desesperador, precisa ser tomado como um impulso para se alçar novos voos no conhecimento. Ele está para ser superado, para que tudo o que até então se tinha como absoluto seja questionado, seja colocado em reflexão. Nessa posição de Nietzsche encontramos, então, o lugar mais propício para o novo humano que, somente consciente da condição de vazio, pode encontrar a liberdade de se lançar em pensamentos dos mais elevados possíveis. Isso torna a consideração nietzschiana hipoteticamente tão otimista quanto feliz. E ele, certamente, a entende deste modo quando não hesita nas palavras de um de seus aforismos: 
Talvez soframos demais as primeiras consequências desse evento - e estas, as suas consequências para nós, não são, ao contrário do que talvez se esperasse, de modo algum tristes e sombrias, mas sim algo difícil de descrever, uma nova espécie de luz, de felicidade, de alívio, contentamento, encorajamento, aurora... De fato, nós, filósofos e "espíritos livres", ante a notícia de que "o velho Deus morreu" nos sentimos como iluminados por uma nova aurora; nosso coração transborda de gratidão, espanto, pressentimento, expectativa - enfim o horizonte nos aparece novamente livre, embora não esteja limpo, enfim os nossos barcos podem novamente zarpar ao encontro de todo perigo, novamente é permitida toda ousadia de quem busca o conhecimento, o mar, o nosso mar, está novamente aberto, e provavelmente nunca houve tanto "mar aberto". (NIETZSCHE, 2012, p. 208).

Desse modo, ambos os filósofos levam a desconsideração de "Deus" às últimas consequências, refletindo acerca dos efeitos disso para o homem ocidental. Além disso, podemos dizer que ambas as perspectivas filosóficas apresentadas contribuem para a elaboração desse território filosófico do não-Deus, cada uma a seu modo, de modo que se possa estabelecer trânsitos entre elas, que nos ajudem a entender as consequências da desconsideração dessa ideia, seja por uma analítica históricofilosófica, seja pela postulação de uma teoria da existência. Desse modo, é possível conceber que o anúncio feito por Nietzsche de que "Deus" está morto, direta ou indiretamente, parece exercer um forte eco nas filosofias posteriores, inclusive no desenvolvimento do existencialismo do filósofo francês.

\section{CONSIDERAÇÕES FINAIS}

Em nossa introdução, levantamos a possibilidade de estabelecermos alguma relação entre a filosofia nietzschiana, especificamente acerca do anúncio da "morte de Deus", e o existencialismo postulado pelo filósofo francês Jean-Paul Sartre. Naquele momento, pressupomos que o que nos parecia mais evidente é que as ideias do filósofo alemão, de tão pertinentes e assertivas em relação à análise do que postula como civilização ocidental, na verdade, poderiam ter ecoado de modo significativo em filosofias posteriores, como no caso do existencialismo sartriano.

Ora, após o desenvolvimento do nosso trabalho, podemos concluir que nossa hipótese parece se sustentar. Isso porque a investigação de Nietzsche acerca da "morte de Deus" como colapso ocidental justifica-se como bastante coerente em relação à realidade vigente na cultura do Ocidente. Tal identificação com a sociedade contemporânea se dá, principalmente, pelo fato da cultura atual estar marcada fortemente por consequências tidas pelo filósofo como próprias do acontecimento da "morte de Deus". Tais consequências são: uma adesão maior ao ateísmo e a perda de sentido dos valores estabelecidos (que Nietzsche identifica como o perigo do niilismo).

Notando, portanto, quão importante se revela a investigação nietzschiana para a filosofia, é possível sustentar que o resultado das ideias desse pensador parece ter influenciado de forma bastante singular o desenvolvimento da filosofia posterior. $\mathrm{O}$ anúncio da "morte de Deus", por ele, pode ter aberto espaços de possibilidade (ou contribuído na constituição de um território filosófico do não-Deus, conforme tenho tratado) na história da filosofia para que se germinasse tipos de pensamentos ateístas como, por exemplo, o de Sartre.

De fato, como vimos, o existencialismo sartriano não pode ser pensado sem o pressuposto do não-Deus. Ele é fundamentalmente sustentado pela descrença em "Deus", de forma que a possibilidade de uma leitura contrária chega a descaracterizar 
vigorosamente o pensamento do filósofo francês. E isso faz com que o diagnóstico nietzschiano acerca do colapso da civilização ocidental se torne cada vez mais propício para o desenvolvimento da filosofia de Sartre. No entanto, volto a dizer que não estou defendendo neste artigo a tese de que Sartre tenha, necessariamente, desenvolvido uma filosofia a partir das concepções de Nietzsche. Inclusive, deixo isso claro na introdução.

De fato, não atribuí a este trabalho um caráter mais acurado de provar que Sartre necessariamente tenha utilizado das ideias do filósofo alemão para a elaboração do seu existencialismo. $\mathrm{Na}$ verdade, parto de uma motivação de estudo histórico e filosófico, debruçando-me sobre grandes obras dos filósofos, pondo as suas ideias em movimento e extraindo delas uma relação possível.

\section{REFERÊNCIAS}

BORNHEIM, Gerd A. Sartre: metafísica e existencialismo. 2. ed. São Paulo: Editora Perspectivas, 1984.

COX, Gary. Compreender Sartre. Trad. Hélio Magri Filho. Petrópolis, RJ: Vozes, 2007.

FRANCK, Didier. As mortes de Deus. In: Cadernos Nietzsche. Trad. Alexandre Filordi de Carvalho. São Paulo, n.19, 2005.

MACHADO, Roberto. Zaratustra, tragédia nietzschiana. Rio de Janeiro: Jorge Zahar Ed., 1997.

MARTON, Scarlett. Nietzsche: das forças cósmicas aos valores humanos. 3. ed. Belo Horizonte: UFMG, 2010.

MARTON, Scarlett. Voltas e reviravoltas - acerca da recepção de Nietzsche na França. In: MARTON, Scarlett (org.). Nietzsche, um "francês" entre os franceses. São Paulo: Editora Barcarolla; Discurso Editorial. 2009.

MELO NETO. João E. T. Nietzsche: o eterno retorno do mesmo, a transvaloração dos valores e a noção de trágico. São Paulo: USP, 2013. 371 f. Tese (Doutorado em Filosofia) Programa de Pós-Graduação em Filosofia, Faculdade de Filosofia, Letras e Ciências Humanas, Universidade de São Paulo, São Paulo, 2013.

NIETZSCHE, Friedrich. A gaia ciência. Trad. Paulo César de Souza. 1. ed. São Paulo: Companhia das Letras, 2012.

NIETZSCHE, Friedrich. Assim falou Zaratustra: um livro para todos e para ninguém. Trad. Paulo César de Souza. São Paulo: Companhia das Letras, 2011.

NOBERTO, Marcelo S. Nietzsche e Sartre: bárbaros da modernidade. In: Cadernos Nietzsche. São Paulo, n.29, 2011.

PERDIGÃO, Paulo. Existência e liberdade: uma introdução à filosofia de Sartre. Porto Alegre: L\&PM, 1995.

PLATÃO. Apologia de Sócrates; Criton. Introdução de Manuel de Oliveira Pulquério. Brasília: Universidade de Brasília, 1997.

PLATÃO. Diálogos: Eutífron ou da religiosidade, apologia de Sócrates, Críton, Fédon. Trad. Márcio Pugliesi e Edson Bini. São Paulo: Hemus, [198-?].

SANTO AGOSTINHO. O livre arbitrio. Trad. Nair de Assis Oliveira. 2. ed. São Paulo: Paulus, 1995.

SARTRE, Jean-Paul. L'existentialisme est um humanisme. Paris: Les Éditions Nagel, 1970.

SARTRE, Jean-Paul. O existencialismo é um humanismo. Tradução de João Batista Kreuch. 2. ed. Petrópolis, RJ: Vozes, 2012.

SARTRE, Jean-Paul. O ser e o nada: ensaio de ontologia fenomenológica. Tradução de Paulo Perdigão. 23. ed. Petrópolis, RJ: Vozes, 2014.

VALADIER, Paul. O divino após a morte de Deus segundo Nietzsche. In: LANGLOIS, Luc; ZARKA, Yves C. (orgs.). Os filósofos e a questão de Deus. Trad. Luiz Paulo Rouanet. São Paulo: Edições Loyola, 2009. 


\section{Notas}

1 Scarlett Marton (2009, p. 26) enfatiza: "Mais uma reviravolta se dá nos anos de 1920. O interesse pelo filósofo [Nietzsche] então ressurge com jovens intelectuais, como JeanPaul Sartre, Simone de Beauvoir, Paul Nizan, Henri Lefebvre, Georges Bataille. Eles se voltam para as suas obras, frustrados com as correntes kantiana e bergsoniana que dominavam a filosofia francesa".

2 "Mas se nos desvencilharmos do que Nietzsche chamava 'a ilusão dos trás-mundos', e não acreditarmos mais no ser-detrás-da-aparição, esta se tornará, ao contrário, plena positividade, e sua essência um 'aparecer' que já não se opõe ao ser, mas, ao contrário, é a sua medida."; "Poderíamos captar o sentido da 'alma' de Pascal (ou seja, de sua 'vida' interior) como 'suntuosa e amarga', tal como Nietzsche a descrevia." (SARTRE, 2014, p. $16 ; 663)$.

3 Ver: Noberto, 2011.

4 Ver: Cox, 2007.

5 Encontramos uma interpretação interessante sobre a morte de Deus como "catástrofe ocidental", como um desmoronamento da sociedade causado pelo arruinamento de uma crença, pelo niilismo, em Paul Valadier (2009); sobre a catástrofe ou colapso ocidental é possível identificar uma interpretação análoga à nossa em João E. T. Melo (2013).

$6 \mathrm{Na}$ Apologia, contudo, Sócrates nunca afirma de forma concreta a imortalidade da alma. No entanto, isso (imortalidade da alma e julgamento no além) é uma constante nos diálogos socráticos.

7 Sobre o deus cristão como referência específica das investigações de Nietzsche, ver: Franck (2005).

8 Neste ponto, concordamos com Marton (2010) no que toca a compreensão que Nietzsche desenvolve na sua investigação dos valores.

9 Sobre a radicalidade da ruptura identificada pelo filósofo alemão com a mudança paradigmática, encontramos um eco de nossa posição na compreensão da morte de Deus, por Roberto Machado (1997).

10 Em relação a isso, seguimos uma linha de interpretação semelhante a que diz respeito ao fato de Nietzsche não ter necessariamente querido provar a existência de Deus, mas, tratar de como e por que surgiu e desapareceu essa crença de que haveria um Deus. Ou seja, o fato deste paradigma deixar de ser plausível (cf. MACHADO, op. cit. p. 47).

11 Por isso, Nietzsche afirma que, mesmo constatada a "morte de Deus", os seus vestígios ainda permanecerão por um longo tempo nas ideias de muitos homens: "Depois que Buda morreu, sua sombra foi mostrada numa caverna durante séculos - uma sombra imensa e terrível. Deus está morto; mas, tal como são os homens, durante séculos ainda haverá cavernas em que sua sombra será mostrada. - Quanto a nós - nós teremos que vencer também a sua sombra." (NIETZSCHE, 2012. p. 126).

12 Cabe aqui também ressaltar a consideração feita por Roberto Machado (1997) de que o superhomem [além-do-homem] é tomado no Assim falava Zaratustra num sentido prospectivo. Ou seja, o super-homem [além-do-homem] só pode ser o sentido da terra se entendido como um alvo a ser atingido, como uma exigência. Enfim, como uma possibilidade de futuro.

13 Encontramos semelhança aqui com o posicionamento de Gerd A. Bornheim (1984).

14 Sobre a questão da ação intencional, percebemos uma posição semelhante à nossa em Gary Cox (2007).

15 Entenda-se aqui o Em si como a realidade que já é. É o ser do fenômeno que se apresenta à consciência. O ser-em-si é o que é. Há aqui uma fusão de identidade entre o si consigo mesmo. Não pode o ser-em-si ser o que será ou deixar de ser o que é, ele é dado, maciço em sua definição.

16 Diferentemente do Em-si, o Para-si se define como sendo o que não é e não sendo o que é. É o existente capaz de refletir sobre si. A grosso modo, o homem é tomado como o Para-si referido por Sartre. É outra região do ser estruturada na possibilidade. Ainda sobre o Parasi, Perdigão (1995, p. 46) diz: "Força que se projeta a si mesma para fora, visando o Em- 
si (ainda que seja para nadificá-lo e, pela imaginação, captar um objeto irreal), o Para-si não tem por si mesmo nenhum conteúdo de Ser".

17 Considerações análogas podem ser encontradas em Perdigão (1995).

18 Sartre enfatiza seu existencialismo ateu justamente porque vale ressaltar que também existiram correntes de existencialismo cristão, como os pensamentos de Jaspers e Gabriel Marcel, citados pelo próprio Sartre (2012) em sua conferência. a partir de nosso ângulo, que somente dele pode-se ter perspectivas. O mundo tornou-se novamente 'infinito' para nós: na medida em que não podemos rejeitar a possibilidade que ele encerre infinitas interpretações.” (NIETZSCHE, 2012, p. 251). 